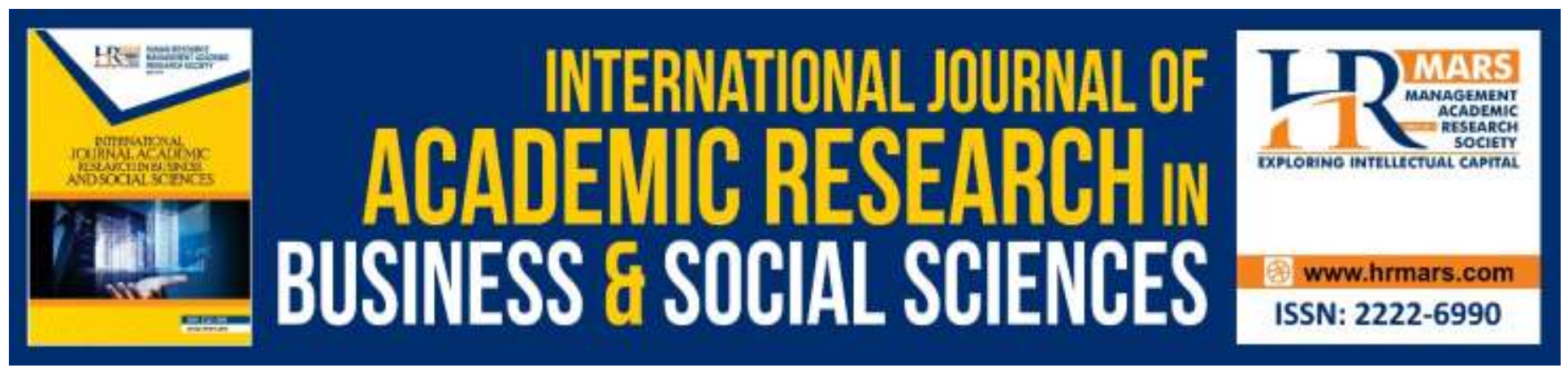

\title{
Training Models for Program Diploma Processing Food Programming in Vocational College Malaysia
}

\author{
Noor Shaziela Mansor, Ridzwan Che' Rus
}

To Link this Article: http://dx.doi.org/10.6007/IJARBSS/v10-i3/7353

DOI:10.6007/IJARBSS/v10-i3/7353

Received: 08 February 2020, Revised: 10 March 2020, Accepted: 16 March 2020

Published Online: 25 March 2020

In-Text Citation: (Mansor \& Rus, 2020)

To Cite this Article: Mansor, N. S., \& Rus, R. C. (2020). Training Models for Program Diploma Processing Food Programming in Vocational College Malaysia. International Journal of Academic Research in Business and Social Sciences, 10(3), 944-950.

Copyright: (C) 2020 The Author(s)

Published by Human Resource Management Academic Research Society (www.hrmars.com)

This article is published under the Creative Commons Attribution (CC BY 4.0) license. Anyone may reproduce, distribute, translate and create derivative works of this article (for both commercial and non-commercial purposes), subject to full attribution to the original publication and authors. The full terms of this license may be seen

at: http://creativecommons.org/licences/by/4.0/legalcode

Vol. 10, No. 3, 2020, Pg. 944 - 950

http://hrmars.com/index.php/pages/detail/IJARBSS

JOURNAL HOMEPAGE

Full Terms \& Conditions of access and use can be found at http://hrmars.com/index.php/pages/detail/publication-ethics 


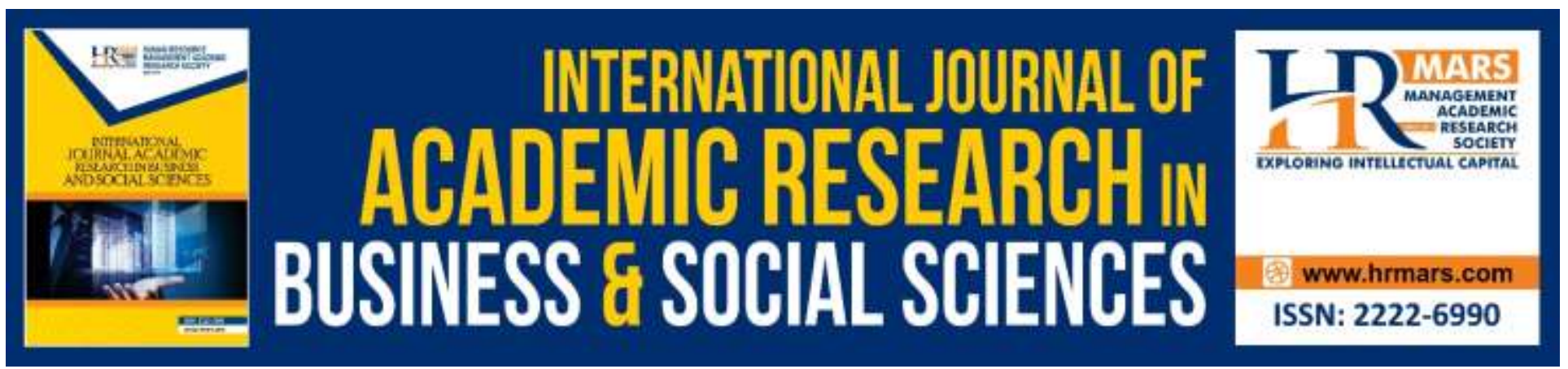

\title{
Training Models for Program Diploma Processing Food Programming in Vocational College Malaysia
}

\author{
Noor Shaziela Mansor, Ridzwan Che' Rus \\ Faculty of Technical and Vocational, Universiti Pendidikan Sultan Idris, Tanjong Malim, Perak.
}

\begin{abstract}
Generic skills are skills that are needed by students other than academics to become more successful and successful as practitioners in academics, jobs, and life. Most countries including Malaysia are having trouble producing more knowledgeable and skilled workers for the advancement of the 2 nd century. The competitive world of work shows that a large number of unemployed graduates are from the social sciences with some notable weaknesses, such as lack of communication skills and creativity skills. In this regard, the study was conducted to produce a Training Curriculum Model for the Diploma in Food Processing Diploma in Malaysian Vocational College. This study aims to explore key components of the GenTy training curriculum model, identify the importance of the GenTy training curriculum model, develop the GenTy training curriculum model and evaluate the effectiveness of the GenTy training curriculum training model for Vocational College Food Processing Diploma students in Malaysia. This study is a development design study using the Design and Develpoment Research (DDR) approach. The study was conducted through three main phases consisting of Phase 1: Needs Analysis Phase using questionnaire method. Next in Phase II: Phase Design and Model Development using Literature Studies, Delphi Fuzzy Studies and Interpretive Structural Modeling (ISM). Next in Phase III: Model Usability Assessment Phase using the Modified Nominal Group Technique. The study sample consisted of 200 students and 100 lecturers of Vocational College randomly selected from four Vocational Colleges in Malaysia with only the subject of Diploma in Food Processing.
\end{abstract}

Keywords: Generic Skills, Communication Skills, Creativity Skills.

\section{Introduction}

Food processing is the process by which a food product is produced. There are various methods used in the processing of food. It is intended to extend the durability and diversify the taste of the food product from the product. The secondary education curriculum in Malaysia, has greatly improved. New subjects related to food processing are being created. These include the subjects of food processing, food delivery, and so on. For food processing subjects, food processing such as chicken nuggets, instant fish crackers, milk, mince, soy and so on. Whereas at institutions of higher learning, there are many courses related to food processing offered. These include courses on Food Preparation and Nutrition, Food Preparation, Food Processing Technology, and more. All of these 
INTERNATIONAL JOURNAL OF ACADEMIC RESEARCH IN BUSINESS AND SOCIAL SCIENCES

Vol. 10, No. 3, March, 2020, E-ISSN: 2222-6990 C 2020 HRMARS

courses are open-minded and provide students with the skills to gain employment opportunities in this growing field.

\section{Problem Statement}

The study was conducted to assess the extent to which the Training Curriculum Model developed for the subject of Food Processing was accepted as a Teaching and Learning material in the subject of Food Processing. The target of using the Training Curriculum Model is for students at Vocational College and lecturers who teach Food Processing subjects at Vocational College of Malaysia.

\section{Research Objective}

i. Discover the key components of the GenTy training curriculum model for Malaysian Vocational College Food Processing Diploma students.

ii. Identify the importance of GenTy training curriculum model to Malaysian Vocational College Food Processing Diploma students.

iii. Develop a training curriculum model for Malaysian Vocational College Diploma in Food Processing students.

iv. Evaluate the effectiveness of the GenTy training curriculum training model from the perspective of administrators and lecturers.

\section{Research Questions}

In order to answer and fulfill the objectives of the research conducted in this development study, the research questions were developed as follows:

i. What is the main component of the GenTy training curriculum model for Malaysian Vocational College Food Processing Diploma students?

ii. What is the significance of the GenTy training curriculum model to Malaysian Vocational College Food Processing Diploma students?

iii. What is the GenTy training curriculum model developed for Malaysian Vocational College Food Processing Diploma students?

iv. How effective is the GenTy training curriculum model from the perspective of administrators and lecturers?

\section{Research Conceptual Framework}

This study is a study of the construction of a GenTy training curriculum model for the Vocational College Food Processing Diploma Program, Malaysia. The construction of this model includes training objectives based on the learning and training provided, training content focused on the elements of generic skills and creativity, training aids that refer to materials that lecturers can use in the process of training and implementing generic and creative elements to students, a teaching strategy (delivery) of training that contains an effective teaching and learning approach. 
INTERNATIONAL JOURNAL OF ACADEMIC RESEARCH IN BUSINESS AND SOCIAL SCIENCES Vol. 10, No. 3, March, 2020, E-ISSN: 2222-6990 @ 2020 HRMARS
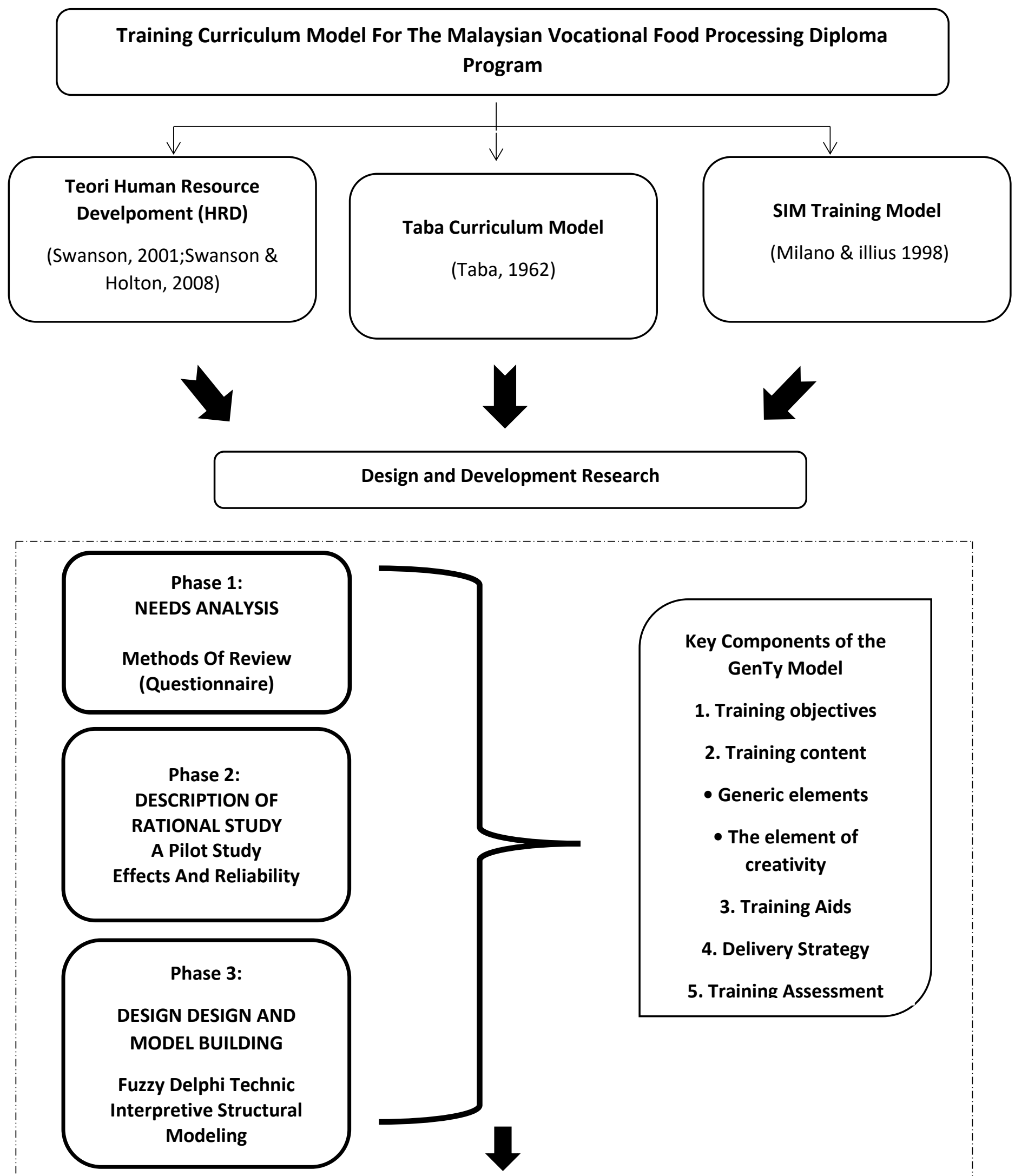

Key Components of the

GenTy Model

1. Training objectives

2. Training content

- Generic elements

- The element of creativity

3. Training Aids

4. Delivery Strategy

5. Training Assessment

GenTy TRAINING CURRICULUM MODEL 


\section{Importance of Study}

The construction of this training curriculum model can also be used in preparation for students pursuing a diploma course in Polytechnic Malaysia. The development of a training curriculum model can also help every lecturer involved with the Food Processing Program at Vocational College, Malaysia to develop knowledge of the generic skills and creativity elements that students will apply in order for students to be more prepared in any field before entering the learning phase. work.

\section{Subject of Study}

The respondents consisted of lecturers and diploma students of the Vocational College pursuing the Diploma in Food Processing Diploma in Vocational College, Malaysia. The study selected 9 experts and used two types of instruments, namely interviews and questionnaires. The construction of the GenTy training curriculum model is also based on expert approval using the Design Development Research Approach. An experimental quasi-experiment was carried out which involved two groups of treatment and control groups randomly selected from four Vocational Colleges in Malaysia. Therefore, the construction of this model goes through several phases to produce a quality and effective model. However, for the third phase of the evaluation phase, the researcher used a usability test involving lecturers who have served for more than five years at Vocational College who are classified as experts. This usability test aims to see the strengths and weaknesses of the GenTy training curriculum model developed.

\section{Methodology}

This study is a study of development design. According to Richey and Klein (2007: 65), the study of model development design is "the systematic study of design, development and evaluation processes with the aim of establishing an empirical basis for a creation of instructional and non-instructional products and tools and new or enhanced models that govern their development. Development design studies are aimed at building models, software, instructional or non-instructional products, new tools or modules. Richey, Klein and Nielson (2007) explain that development design studies involve the design, development, evaluation and overall or part-specific process. The study was conducted through three main phases consisting of the needs analysis phase, the design and development phase of the model and the model usability phase. Training curriculum models that focus on generic elements and creativity are used in this phase which include key components namely training objectives, training content, training aids, teaching strategies and training evaluation. The SIM (Sequential Iterative Model) model and the TABA curriculum model are fundamental to the key components of developing this GenTy training curriculum model.

In this study, the researchers used a quasi-experimental method in which there were two groups, the control group and the treatment group. Design of a quasi-experimental study conducted at four vocational colleges namely Chenor Vocational College, Pahang, Dato Lela Emperor College, Negeri Sembilan, Teluk Intan Vocational College, Perak and Lahad Datu Vocational College, Sabah which was randomly selected for treatment group and control groups.

In the first phase of the needs analysis phase there are generic elements and creativity will be conducted through the survey methodology to identify the needs in developing the GenTy training 
INTERNATIONAL JOURNAL OF ACADEMIC RESEARCH IN BUSINESS AND SOCIAL SCIENCES

Vol. 10, No. 3, March, 2020, E-ISSN: 2222-6990 @ 2020 HRMARS

curriculum model for Diploma in Food Processing students. The respondents were comprised of Vocational College students pursuing a Diploma in Food Processing. The research conducted in this phase is focused on the need to develop the GenTy training curriculum model and see the need for generic elements and creativity in the Diploma in Food Processing Diploma program students at Vocational College.

In the second phase, which is the design phase of the rational study, the researcher conducts a pilot study. Pilot studies are small-scale studies that are conducted before actual studies are conducted. This pilot study was conducted to see the validity of a study to be conducted. Pilot study is an important part of a rational study. The pilot study did not guarantee the success of the main study but did little to help researchers identify the level of validity of the main study to be carried out (Chua, 2011). This pilot study will be conducted at the Vocational College of 50 respondents. As discussed earlier, the questionnaire items of the questionnaire were categorized based on two elements of study namely the generic skills element and the creativity element based on the research questions in the needs analysis phase.

In the third phase, which is the design and construction phase of the model, the researcher has applied the Fuzzy Delphi method approach, which is the framework used in conducting the study by collecting and analyzing the opinion of a group of experts in the selected field of study. The construction of this model is to look at the priority of each item within the main component. It should be reiterated that the Delphi method is a technique and approach used to review and gather a consensus of structured experts (Imran, 2007; Adler \& Ziglio, 1996). Whereas Linstone and Turoff (2002) stated that the Delphi method is a method of decision making through several rounds of questionnaires to obtain expert opinion on an issue or matter being studied. Delbecq's assertion, Van de Ven and Gustafson (1975), is referred to as the Delphi method which is able to systematically find expert consent points using a set of questionnaires that have been developed based on the expert's own opinion. Hill and Fowles (1975) emphasize that the Delphi method can be a tool for making predictions and forecasts of an issue for the future based on the views of a group of experts relevant to an issue. The conclusions of the experts above prove that the Delphi method is an effective means of making a decision in which the respondents involved are those who are well versed in a particular issue and study. Therefore, studies based on the Delphi method require researchers to conduct interviews with respondents to get their views on the issues being studied. However, the process of obtaining this issue can also be carried out using other alternative methods such as literature search (Chang, Hsu \& Chang, 2011; Dullfield's, 1993). This is in line with Powell's (2003) view that the Delphi method is very flexible where the main purpose of this method is to make a decision based on the consensus of the expert group.

In the fourth phase of the model's usability assessment phase, researchers will look at the aspects of expert satisfaction that are among the lecturers involved in the Vocational College Food Processing Diploma program to evaluate the usability of the training curriculum model to be developed. This aspect of satisfaction refers to measuring expert opinion on the usefulness of the model in helping them train and apply the elements of generic skills and creativity to Diploma in Food Processing students. This is referred to on the basis of Jeng and Tzeng (2012) who assert that a product being developed can be seen as useful through the opinions and perceptions of experienced users (experts) in using the product. In this phase of usability assessment, the model was presented 
INTERNATIONAL JOURNAL OF ACADEMIC RESEARCH IN BUSINESS AND SOCIAL SCIENCES

Vol. 10, No. 3, March, 2020, E-ISSN: 2222-6990 C 2020 HRMARS

and presented to a team of experts in Food Processing Lecturers who have more than 5 years teaching experience in Food Processing at Vocational College.

\section{Conclusion}

In conclusion, the study was to develop a GenTy training curriculum model for the Diploma in Food Processing Diploma Program at the Vocational College of Malaysia. Literature studies show administrators at Vocational College are still using conventional and still weak ways to incorporate elements of generic skills and creativity in their students. This training curriculum model is expected to help improve the effectiveness and quality of inculcating generic elements and creativity among the lecturers and students of the Food Processing Diploma Program at Vocational College, Malaysia.

\section{References}

Adler, M., \& Ziglio, E. (1996). Gazing into the oracle: The Delphi method and its application to social policy and public health. London: Jessica Kingsley Publishers.

Chua, Y. P. (2011). Kaedah Penyelidikan Edisi Kedua. Kuala Lumpur: McGraw Hill.

Chang, P. T., Huang, L. C., \& Lin, H. J. (2011). The Fuzzy Delphi method via fuzzy statistics and membership function fitting and an application to the human Resource. Fuzzy Sets and Systems,112(3), 511-520.

Duffield, C. (1993) The Delphi Technique: a comparison of results obtained using two expert panels. International Journal of Nursing Studies, 30, 227-237.

Hill, K. Q., \& Fowles, J. (1975). The methodological worth of the Delphi forecasting technique. Technology and Forecasting and Social Change,7(2), 179-192.

Jeng, D. J. F., \& Tzeng, G. H. (2012). Social influence on the use of clinical decision support systems: Revisiting the unified theory of acceptance and use of technology by the fuzzy DEMATEL technique. Computers \& Industrial Engineering, 62(3), 819-828.

Linstone, H. A., \& Turoff, M. (2002). The Delphi method: Techniques and applications. Boston, MA: Addison-Wesley

Milano, M., \& Ullius, D. (1998). Designing powerful training, The Sequential-Iterative Model. Jossey-Bass/Pfeiffer. A Wiley Company, San Francisco

Imran, M. Y. (2007). The Delphi Technique. Essays in Education, 20, 80-89.

Powell, C. (2003). The Delphi technique: myths and realities. Journal of Advanced Nursing, 41(4), 376-382.

Richey, R., \& Klien, J. (2007). Design and development research: Method, Strategies and Issues. London: Erlbaum.

Swanson, R. A., \& Holton, E. F. (2008). Foundations of Human Resource Development. Berrett-Koehler Publishers, Inc.

Taba, H. (1962). Curriculum development; theory and practice. New York: Harcourt Brace \& World

Van de Ven, A., and Delbecq, A.L. (1975). Nominal versus Interacting Group Processes for Committee Decision-Making Effectiveness. Academy of Management Journal, 14(2), 203 -212. 